Article

\title{
The Self-Seeding of Anthemis arvensis L. for Cover Crop in Olive Groves under Intense Rabbit Grazing
}

\author{
Antonio J. Carpio ${ }^{1,2, *} \mathbb{0}$, María-Auxiliadora Soriano ${ }^{3}$, José A. Gómez ${ }^{4}(\mathbb{D}$ and \\ Francisco S. Tortosa ${ }^{1}$ \\ 1 Department of Zoology, University of Cordoba, Campus de Rabanales, 14071 Córdoba, Spain; \\ ba1satof@uco.es \\ 2 Institute for Research in Hunting Resources (IREC), Ronda de Toledo s/n, 13071 Ciudad Real, Spain \\ 3 Department of Agronomy, University of Cordoba, Campus de Rabanales, 14071 Córdoba, Spain; \\ ag1sojim@uco.es \\ 4 Institute for Sustainable Agriculture (CSIC), Alameda del Obispo s/n, 14004 Córdoba, Spain; \\ joseagomez@ias.csic.es \\ * Correspondence: b42carca@uco.es or Antonio.Carpio@uclm.es; Tel.: +34-669289891
}

Received: 7 August 2020; Accepted: 15 September 2020; Published: 17 September 2020

\begin{abstract}
Cover crops can be an effective means to protect soil and reduce risks of erosion in olive groves. However, for this protection to be significant, the vegetation must attain a significant amount of ground cover, which is estimated to be at least 30\% during the rainy season. In olive groves on degraded soils, which occupy large surface areas in the olive-growing areas of the Mediterranean region, the establishment of cover crops may be an arduous challenge, particularly in areas with a high density of rabbits. In this study, we have selected two olive orchards with scarce natural vegetation located in Andalusia (southern Spain), in which rabbit populations intensively forage the cover crops, to test whether the self-seeding of an unpalatable species corn chamomile (Anthemis arvensis L.; A. arvensis for short) could achieve sufficient coverage for soil protection, in the year following that in which the broadcast-seeding was carried out for the implementation of cover crops. The hand broadcast-seeding of $A$. arvensis was carried out on sixteen elementary plots in the lanes of the two olive orchards in the autumn of 2015, and seed germination in the subsequent self-seeding took place in the autumn of 2016. The plant height and A. arvensis ground cover in these plots were measured throughout the two growth cycles, and aerial biomass was measured at maturity. The results showed that there were no significant differences in the maximum plant height between the two growth cycles (mean \pm SD of $21.2 \pm 1.6 \mathrm{~cm}$ ), while the ground cover was significantly greater in the case of self-seeding, especially during the winter (37.2 \pm 8.1 and $9.3 \pm 6.7 \%$ for self-seeding and broadcast-seeding, respectively), and aerial biomass at maturity had more than doubled ( 99.7 and $43.9 \mathrm{~g} \mathrm{~m}^{-2}$, respectively). These data suggest that this unpalatable species could establish an effective herbaceous cover by means of self-seeding in olive groves on degraded soils that are being overgrazed owing to the high pressure of rabbits. Despite the poor establishment in the broadcast-seeding year, our findings indicate that $A$. arvensis might be an alternative cover crop that could help the sustainability of these threatened olive groves. Its high seed production (2000 to 4000 seeds per plant), and an early emergence just after the first autumn rains, should result in an increased ground cover by $A$. arvensis during the rainy season in the subsequent years of self-seeding. This, therefore, could contribute to soil conservation, in addition to providing other benefits of increased biodiversity and improvement for agricultural landscapes.
\end{abstract}

Keywords: Andalusia; agricultural sustainability; biodiversity; herbaceous cover; soil conservation 


\section{Introduction}

Soil erosion is one of the most serious and widespread environmental threats in the Mediterranean Basin, and is closely related to not only geo-ecological factors (lithology, topography and climatology), but also changes in land use and vegetation cover [1]. This is evident throughout the Mediterranean region, where changes in soil management, which are characterized by the intensification and mechanization of tillage and the use of herbicides, have been extensive and rapid in recent decades. This has led to an increase in the surface area of bare soils, which has caused accelerated soil loss and soil degradation on much agricultural land, accompanied by various negative economic and environmental impacts [2-5]. The severe problems of soil erosion are clearly visible and worrying in the olive-growing areas of Andalusia (southern Spain) [6,7], in which olive trees dominate the landscape in an impressive monoculture that occupies about 1.6 million ha (or $18 \%$ of the total regional surface) [8].

The sustainable management of natural resources is one of the key aspects of the EU's common agricultural policy (CAP) [9], including goals such as the conservation of our soils and biodiversity. In this context, one of the most effective measures by which to reduce soil erosion is the use of cover crops [10-12], a practice that has been promoted through subsidies and cross compliance from the CAP [13]. The use of cover crops in the lanes of olive groves has been shown to have a beneficial environmental impact on experimental orchards by reducing soil erosion $[14,15]$ and increasing biodiversity [16-18]. However, the establishment of cover crops in commercial olive orchards raises various agro-economic and practical issues, especially in rain-fed orchards, owing to the competition between olive trees and cover crops for soil water. In addition, highly degraded soils (owing to compaction, poor soil fertility and the loss of seed banks), along with overgrazing owing to the high abundance of European rabbits (Oryctolagus cuniculus L.) make it very difficult to establish an herbaceous cover with a significant effect on reducing water erosion (covering a minimum percentage of at least $30 \%$ of soil) in these olive orchards [19].

The overgrazing of cover crops owing to the high density of rabbits was addressed in a previous work using two native species of annual plants, red brome (Bromus rubens L.; Poaceae) and corn chamomile (Anthemis arvensis L.; Asteraceae). It was carried out in a context of natural food scarcity (olive groves on degraded soils with a very low density and diversity of weeds), without the rabbits having any negative effect on the growth of $A$. arvensis, while B. rubens was massively consumed [20]. The role of cover crops in preventing soil erosion is ineffective when they do not attain sufficient soil coverage, which is estimated to be at least $30 \%$ during the rainy season [21,22]. This percentage of ground cover was not attained in the study carried out by Carpio et al. [20], and is greater than the coverage attained by $A$. arvensis when measured by Carpio et al. [20]. In addition to the influence of ecological and local environmental factors, to ensure that the adoption of an alternative cover crop (e.g., A. arvensis) by farmers will not be limited by economic factors, it is also necessary that the cover crop will guarantee a high capacity for self-seeding. In the aforementioned study by Carpio et al. [20], $A$. arvensis was seeded by means of hand-broadcasting, although self-seeding has been shown to be more effective for the earlier establishment of pasture, which would lead to a faster and greater ground coverage in winter $[23,24]$. Corn chamomile is a native annual flowering plant with a short life cycle and early maturity that germinates in autumn and wilts from early to mid-spring, thus limiting the risk of competition for water with olive trees $[25,26]$. It is characterized by its short height (up to a maximum of $30 \mathrm{~cm}$ ), which minimizes disturbance for farmers when carrying out agricultural tasks, since it has also been identified as moderately resistant to trampling [27].

The aim of this study was, therefore, to test the effectiveness of the self-seeding of an unpalatable species (Anthemis arvensis L.) in olive groves on degraded soils, in a context of high rabbit density and of scarce natural food resources, in the year following that in which the broadcast-seeding was carried out. We hypothesized that the self-seeding of $A$. arvensis would cover a larger soil surface, exceeding the threshold of 30\%, despite a poor establishment in the hand broadcast-seeding year, thus contributing to soil conservation and to the sustainability of these olive groves. 


\section{Materials and Methods}

\subsection{Study Area}

The experimental plots were established in two commercial olive orchards located in the south of the province of Cordoba (Andalusia). This region is characterized by a Mediterranean climate (with an annual average rainfall and evaporative demand of 524 and $1418 \mathrm{~mm}$, respectively, and monthly mean temperatures for the coldest and warmest months, respectively, of $9.2^{\circ} \mathrm{C}$ in January and $27.5^{\circ} \mathrm{C}$ in July, over a 17-year span; [28]). The main crops in the study area are olives (Olea europaea L.) and vineyard grapes (Vitis vinifera L.). The sport hunting of rabbits is a very popular activity in this area owing to their high densities, and these herbivores are even considered to be a pest species in the study area owing to the large amount of damage caused to field crops, vineyards and young olive trees [29]. Additionally, soil erosion is a serious problem in most of the olive groves in this area.

The two olive orchards selected ( $8 \mathrm{~km}$ apart from each other) were on compacted soils, with extremely scarce vegetation cover, and with a high density of rabbits. Since rabbits have previously been reported to cause severe damage to cover crops in the study area [19], the choice of A. arvensis as a cover crop is justified, as it is considered to be an unpalatable species that is highly resistant to predation by rabbits because of the chemical composition and antimicrobial activity of its essential oils [30]. The soil type in both olive orchards was, according to the FAO (Food and Agriculture Organization) system [31], Alfisol, and the two soils had a similar silty-clay-loam texture (mean values of $34.7 \%$ clay and $46.7 \%$ silt) and organic matter content (an average of $1.43 \%$ ) for the depth of $0-10 \mathrm{~cm}$.

\subsection{Experimental Design and Measurements}

In each olive orchard, eight elementary plots $(3 \times 3 \mathrm{~m})$ randomly distributed in the lanes were established in autumn 2015. The seeds of Anthemis arvensis were hand-broadcast in each elementary plot in autumn (9 November 2015), using a dose of $0.1 \mathrm{~g} \mathrm{~m}^{-2}$ or 850 seeds $\mathrm{m}^{-2}$ (approximately $80 \%$ germination), and $30 \mathrm{~kg} \mathrm{~N} \mathrm{ha}^{-1}$ (as ammonium sulphate, 21\% N) was added simultaneously with the seed, both of which were incorporated into the soil using a mini rotary cultivator. In addition, two weeks after sowing, a light irrigation ( $16 \mathrm{~mm}$ ) was applied using a micro-sprinkler system to facilitate the emergence and establishment of seedlings. In autumn 2016, A. arvensis (hereafter denominated as Aa) was naturally re-established by self-seeding in the same plots. Machinery traffic was excluded from all plots.

The growth of the plant height and ground covered by Aa were measured approximately every three to four weeks, from November to April, throughout the two life cycles. The percentage of ground surface covered by Aa plants was calculated through the use of plot-surface images, following the methodology developed by Luscier et al. [32]. The height of the vegetation was calculated as the average measurement at 10 random points $\left(0.01-\mathrm{m}^{2}\right)$ on each elementary plot. Aerial biomass was measured in mid-spring, once Aa had reached maturity. Aboveground biomass was calculated by sampling three areas of $0.25 \mathrm{~m}^{2}$ on each elementary plot, on which the vegetation was cut. These cutting areas were randomly selected within each plot. Plant samples were dried in an oven at $70{ }^{\circ} \mathrm{C}$ and the dry weight was converted to $\mathrm{g}^{-2}$.

The rainfall in both olive orchards was recorded every $60 \mathrm{~min}$ by means of a high-resolution rain gauge, and atmospheric water demand or reference evapotranspiration (ETo) (FAO Penman-Monteith method; [33]) was obtained each day from the Santaella agro-meteorological station [28], which is located approximately $18 \mathrm{~km}$ from the olive orchards. The two climatic variables were accumulated daily from the beginning of each agricultural year until the end of the Aa growth cycle, (Table 1). The rainfall recorded in the olive orchards (from 1 September to 30 April, for the years 2015-2016 and 2016-2017) was $367 \mathrm{~mm}$ and $318 \mathrm{~mm}$, respectively. The ETo during the same periods was $584 \mathrm{~mm}$ and $636 \mathrm{~mm}$, respectively. 
Table 1. Cumulative monthly precipitation and evapotranspiration (ETo) (mm) during the two agricultural seasons in which the study was carried out. The precipitation $(\mathrm{P})$ was the average recorded in the two olive orchards evaluated, and the ETo was obtained from the Santaella agro-meteorological station.

\begin{tabular}{ccccc}
\hline \multirow{2}{*}{ Date } & \multicolumn{2}{c}{$\mathbf{2 0 1 5 - 2 0 1 6}$} & \multicolumn{2}{c}{ 2016-2017 } \\
\cline { 2 - 5 } & $\mathbf{P}(\mathbf{m m})$ & ETo $(\mathbf{m m})$ & $\mathbf{P}(\mathbf{m m})$ & ETo $(\mathbf{m m})$ \\
\hline 30 September & 10 & 139 & 3 & 157 \\
31 October & 63 & 217 & 80 & 249 \\
30 November & 119 & 268 & 146 & 292 \\
31 December & 123 & 311 & 146 & 325 \\
31 January & 194 & 345 & 162 & 368 \\
28 February & 242 & 393 & 199 & 414 \\
31 March & 264 & 480 & 278 & 504 \\
30 April & 367 & 584 & 318 & 636 \\
\hline
\end{tabular}

\subsection{Statistical Analysis}

Two generalized linear mixed models were applied, using the plant height and ground cover attained by Aa on each elementary plot as the response variables. In these models, "sowing method" (hand broadcast-seeding or self-seeding) and "date" throughout the growth cycle (six levels) were considered as categorical independent variables, while "olive orchard" (two levels) was considered as a random factor. Assumptions of normality and independence were confirmed, and variance structure (varIdent) was added to the models to ensure homogeneity in the residual spread. This allowed the residuals to have a different spread across the levels of a categorical variable (in our case, the variance covariate was "date"). Fisher's Least Significant Difference (LSD) post-hoc test was also applied to check for response differences among different levels of categorical variables and the interaction.

Differences in the maximum plant height and maximum ground cover, and in the aerial biomass dry weight of Aa between the self-seeding and broadcast-seeding plots ( $n=16$ pairs), were checked using a Wilcoxon paired test. InfoStat software was used in all the statistical procedures.

\section{Results}

With regard to the Aa models (plant height and ground cover), the "sowing method" was significant $(p<0.0001)$ for both models (Table 2), since the plant height of Aa was, throughout its entire growth cycle, higher in the year of self-seeding than in the year of cover crop establishment by hand broadcast-seeding (general mean values \pm SD of $13.6 \pm 7.2 \mathrm{~cm}$ and $9.0 \pm 8.0 \mathrm{~cm}$, respectively). This was also the case of the Aa ground cover (30.4 $\pm 10.7 \%$ for self-seeding and $10.8 \pm 7.3 \%$ for broadcast-seeding, for the whole growth cycle). The "date" was also significant for the plant height and ground cover models $(p<0.0001)$ (Table 2), owing to the fact that throughout the development cycle there is growth in plant height and vegetation cover (up to the maximum around March).

Table 2. Fixed effects (F) of the explanatory variables on ground cover and height of $A$. arvensis; $\mathrm{df}$ refers to degree of freedom of the numerator; df of denominator $=125$ (Fisher's LSD test).

\begin{tabular}{cccccc}
\hline \multirow{2}{*}{ Variables } & \multirow{2}{*}{ df } & \multicolumn{2}{c}{ Ground Cover } & \multicolumn{2}{c}{ Plant Height } \\
\cline { 3 - 6 } & & $\mathbf{F}$ & $\boldsymbol{p}$-Value & $\mathbf{F}$ & $\boldsymbol{p}$-Value \\
\hline (Intercept) & 1 & 5.39 & 0.0219 & 8.84 & 0.0035 \\
Sowing Method & 1 & 237.31 & $<0.0001$ & 88.48 & $<0.0001$ \\
Date (growth cycle) & 5 & 25.57 & $<0.0001$ & 133.78 & $<0.0001$ \\
Sowing Method $\times$ Date & 5 & 13.87 & $<0.0001$ & 5.36 & 0.0002 \\
\hline
\end{tabular}

Maximum plant height was attained in early spring (Figure 1), with average values $( \pm \mathrm{SD}$ ) of $22.3 \mathrm{~cm}( \pm 8.5)$ for self-seeding and $20.0 \mathrm{~cm}( \pm 4.9)$ for hand broadcast-seeding, without significant 
differences $(p>0.1)$. With regard to percentage ground cover by Aa plants, Figure 2 shows how the maximum coverage was attained in late winter for self-seeding and in early spring for broadcast-seeding, approximately one week after full flowering. Significant differences were observed (Wilcoxon test; $p<0.001$ ) between the mean values of the maximum coverage attained by Aa in the year of self-seeding $(46.5 \pm 16.9 \%)$ when compared to the year of broadcast-seeding $(23.4 \pm 7.8 \%)$. Wilcoxon's test also showed significant differences $(p<0.05)$ between self-seeding and broadcast-seeding as regards the Aa aerial biomass dry weight at maturity $\left(99.7 \pm 22.3 \mathrm{~g} \mathrm{~m}^{-2}\right.$ for self-seeding and $43.9 \pm 21.7 \mathrm{~g} \mathrm{~m}^{-2}$ for broadcast-seeding).

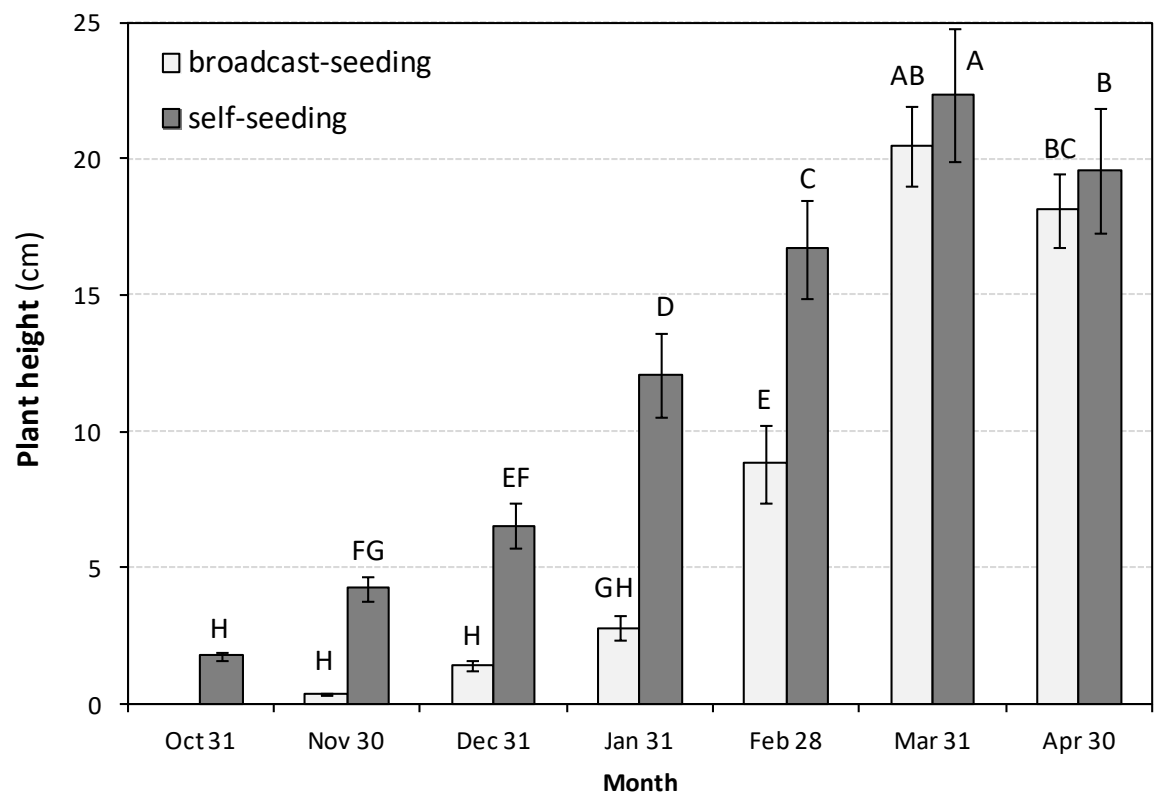

Figure 1. Plan height $(\mathrm{cm})$ of A. arvensis throughout its growth cycle for the two agricultural seasons evaluated, according to the sowing method (mean values). Error bars are standard error of the mean. Different capital letters indicate significant differences $(p=0.05)$ in monthly plant height between both sowing systems according to Fisher LSD tests.

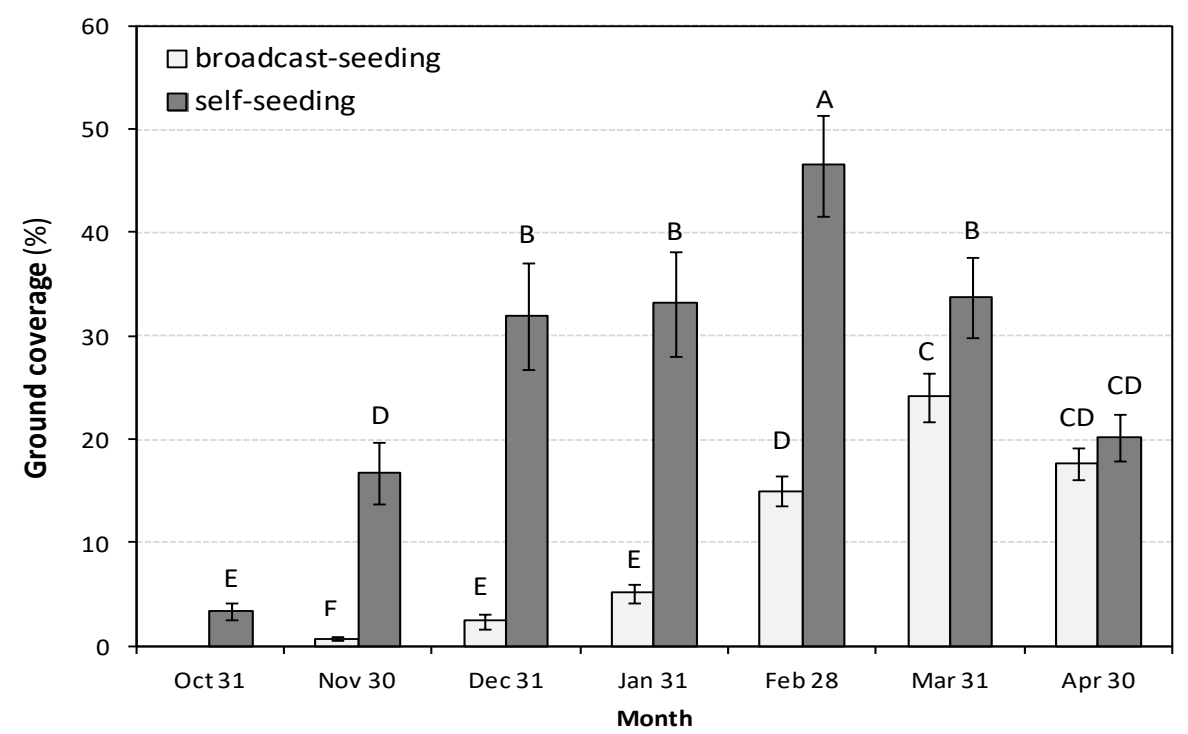

Figure 2. Change in ground coverage (\%) by A. arvensis throughout its growth cycle for the two agricultural seasons evaluated, according to the sowing method (mean values). Error bars are standard error of the mean. Different capital letters indicate significant differences $(p=0.05)$ in monthly ground coverage between both sowing systems according to Fisher LSD tests. 
In the case of self-seeding, average ground coverage by Aa $>30 \%$ was attained at the end of autumn (Figure 2), signifying that the soil could remain protected against the risk of water erosion throughout the winter and until mid-to-late spring, a period in which more than two-thirds of the annual rainfall that falls in the study area is recorded [28]. However, in the case of broadcast-seeding, $30 \%$ of the ground cover by Aa occurred very late in the winter, and only on a few elementary plots, on which the soil coverage achieved by self-seeding exceeded $60 \%$. These differences in the growth of Aa between both agricultural seasons (or "sowing method") were not related to the precipitation or the evaporative demand, since both the total amount and the distribution of rainfall were similar, as was also in the case of the ETo, during the two growth cycles of Aa. More so, if it is taken into account that a little less rainfall and a little more ETo were recorded in the year of self-seeding (Table 1).

Ground coverage by Aa plants progressively decreased during the stepped maturation of the seeds owing to leaf senescence and fall (Figure 2), although these plant residues on the soil surface contribute to helping protect the soil against erosion until they are decomposed, from mid-to-late spring. A slight decrease in vegetation height was similarly measured after Aa attained its maximum height (Figure 1). This could be attributed to the variability in the time at which the seedlings emerge, since early emergence seems to have competitive advantage as regards the growth of the seedlings and the size attained by a plant in a population, which will also complete its life cycle earlier.

\section{Discussion}

Our results, despite being obtained in olive groves on degraded soils under intense rabbit grazing, showed that the self-seeding of $A$. arvensis allowed the average soil coverage from late autumn onwards to exceed the critical threshold of $30 \%$ that is estimated to be the minimum value to have a significant effect in reducing soil erosion by water [21,22]. According to this threshold value, vegetation cover helps to reduce sediment yields from natural and agricultural areas in the Mediterranean region by intercepting the kinetic energy of rainfall, and by reducing the amount and velocity of runoff [34-36], although the minimum percentage of ground cover required to reduce soil erosion was not attained during the year in which hand broadcast-seeding was carried out to implement the cover crop. However, the self-seeding in the following agricultural year achieved the required vegetation coverage sufficiently early to protect the topsoil against erosion from the end of autumn, despite the fact that these areas undergo intense herbivory by rabbits. The seed germination of $A$. arvensis appears to increase substantially after four months of the achenes being stored in the soil, as the seeds have a tough seed coat (pericarp) that must be softened before germination can occur [27]. Soil microorganisms, faunal digestive systems, and perhaps soil moisture-temperature cycles, remove the seed coat [37,38]. In the case of self-seeding, therefore, the fact that the achenes have remained in the field for a few months (late spring-to-early autumn) allows this physical barrier to be broken and seed germination to take place sooner. This early emergence, just after the first autumn rains, will accelerate initial plant growth owing to the high temperatures in early and mid-autumn in this region, which will allow the attainment of a faster and greater $A$. arvensis ground cover during the winter. In addition, an early emergence also allows an earlier flowering and maturity, which will limit competition with the olive trees for soil water.

Although the benefits of using cover crops in Mediterranean woody crops have been well documented on experimental farms, on which they have been shown to reduce runoff and soil loss and increase biodiversity [11,18,39], the adoption of cover crops in commercial orchards has, to date, been constrained by economic and ecological factors, and by various management problems $[14,15]$. In order to ensure that farmers will not hesitate to use this agro-environmental technique, identifying new alternative native plant species whose implementation is easy and cost-effective, thus helping overcome existing barriers to their adoption, has become a continuous research goal. This study has shown that the self-seeding of $A$. arvensis achieved sufficient vegetation cover in winter to help protect the soil against erosion in the first year of self-seeding, despite a context of high rabbit densities and natural food scarcity. An average-sized A. arvensis plant commonly produces 2000 to 4000 seeds, which 
can remain alive for several years [27,38]. This feature should result in an enhancement and increased ground cover by $A$. arvensis in the subsequent years of self-seeding, signifying that this unpalatable species could be a viable alternative as regards providing a cover crop in woody crops in areas of high grazing pressure. The self-seeding of $A$. arvensis could, therefore, be an effective aid with regard to soil conservation in these threatened olive groves during the winter and until the middle of spring (the rainy season in Mediterranean environments, during which the risk of soil erosion increases considerably) by means of vegetation and residue cover, which would contribute to increasing the sustainability of these olive groves in Andalusia, and also to greater on-farm biodiversity and an improvement to the agricultural landscape.

\section{Conclusions}

The self-seeding of A. arvensis has been shown to be an efficient cover crop in winter-spring, since it covers the ground above the minimum threshold required to reduce soil erosion. Self-seeding promotes the early emergence of seedlings, just after the first autumn rains, which stimulates the early plant growth owing to the high temperatures in this region in early and mid-autumn reinforcing its soil protection role. It additionally allows the reduction in agricultural labor and costs and we, therefore, suggest the use of this species in areas in which overgrazing by rabbits prevents the use of alternative palatable herbaceous species. Further research is required in order to identify new cover crops for their establishment in olive orchards on degraded soils with a high density of rabbits, as well as follow their performance under machinery traffic conditions typical of olive orchards.

Author Contributions: J.A.G., M.-A.S., A.J.C. and F.S.T. conceived and designed the experiment. J.A.G., A.J.C., and M.-A.S. implanted the plots. A.J.C. performed the data collections with support from J.A.G., and M.-A.S. A.J.C. and M.-A.S. analysed the data. A.J.C., M.-A.S., J.A.G. and F.S.T. wrote the first draft of the manuscript, and all authors contributed to the final version of the manuscript. All authors have read and agreed to the published version of the manuscript.

Funding: This work was supported by the projects AGL2015-65036-C3-1-R of the Spanish Ministry of economy and competitiveness, P12-AGR-931 and EU-FEDER (Fondo Europeo de Desarrollo Regional) funds. AJC was funded by a FPI (formación de personal investigador) pre-doctoral scholarship provided by MINECO (Ministry of economy and competitiveness).

Acknowledgments: We would like to thank Simon for his helpful comments on the manuscript and the farmers for their cooperation. We are also grateful to the estate owners for their hospitality and assistance. This work was supported by the projects AGL2015-65036-C3-1-R of the Spanish Ministry of economy and competitiveness and P12-AGR-931, and EU-FEDER funds. AJC was funded by a FPI pre-doctoral scholarship by MINECO.

Conflicts of Interest: The authors declare no conflict of interest.

\section{References}

1. García-Ruiz, J.M. The effects of land uses on soil erosion in Spain: A review. Catena 2010, 81, 1-11. [CrossRef]

2. Symeonakis, E.; Calvo-Cases, A.; Arnau-Rosalen, E. Land use change and land degradation in South-eastern Mediterranean Spain. Environ. Manag. 2007, 40, 80-94. [CrossRef] [PubMed]

3. Scheidel, A.; Krausmann, F. Diet, trade and land use: A socio-ecological analysis of the transformation of the olive oil system. Land Use Policy 2011, 28, 47-56. [CrossRef]

4. Muñoz-Rojas, M.; Jordán, A.; Zavala, L.M.; de la Rosa, D.; Abd-Elmabod, S.K.; Anaya-Romero, M. Impact of land use and land cover changes on organic carbon stocks in Mediterranean soils (1956-2007). Land Degrad. Dev. 2015, 26, 168-179. [CrossRef]

5. Panagos, P.; Standardi, G.; Borrelli, P.; Lugato, E.; Montanarella, L.; Bosello, F. Cost of agricultural productivity loss due to soil erosion in the European Union: From direct cost evaluation approaches to the use of macroeconomic models. Land Degrad. Dev. 2018, 29, 471-484. [CrossRef]

6. Milgroom, J.; Soriano, M.A.; Garrido, J.M.; Gómez, J.A.; Fereres, E. The influence of the shift from conventional to organic olive farming on soil management and erosion risk in Southern Spain. Renew. Agric. Food Syst. 2007, 22, 1-10. [CrossRef] 
7. Gómez, J.A.; Infante-Amate, J.; González de Molina, M.; Vanwalleghem, T.; Taguas, E.V.; Lorite, I. Olive Cultivation, its Impact on Soil Erosion and its Progression into Yield Impacts in Southern Spain in the Past as a Key to a Future of Increasing Climate Uncertainty. Agriculture 2014, 4, 170-198. [CrossRef]

8. CAGPDS (Consejería de Agricultura, Ganadería, Pesca y Desarrollo Sostenible). Avance de Superficies y Producciones; Junta de Andalucía, CAGPDS: Seville, Spain; Available online: https://www.juntadeandalucia.es/organismos/agriculturaganaderiapescaydesarrollosostenible/consejeria/ sobre-consejeria/estadisticas/paginas/agrarias-superficies-producciones.html (accessed on 11 July 2019).

9. EC (European Commission). The Common Agricultural Policy at a Glance. Aims of the Common Agricultural Policy; EC: Brussels, Belgium; Available online: https://ec.europa.eu/info/food-farming-fisheries/key-policies/ common-agricultural-policy/cap-glance_en\#title (accessed on 11 July 2019).

10. Langdale, G.W.; Blevins, R.L.; Karlen, D.L.; McCool, D.K.; Nearing, M.A.; Skidmore, E.L.; Thomas, A.W.; Tyler, D.D.; Williams, J.R. Cover crop effects on soil erosion by wind and water. In Cover Crops for Clean Water; Hargrove, W.L., Ed.; Soil and Water Conservation Society: Ankeny, IA, USA, 1991; pp. 15-22.

11. Gómez, J.A.; Llewellyn, C.; Basch, G.; Sutton, P.B.; Dyson, J.S.; Jones, C.A. The effects of cover crops and conventional tillage on soil and runoff loss in vineyards and olive groves in several Mediterranean countries. Soil Use Manag. 2011, 27, 502-514. [CrossRef]

12. Ruiz-Colmenero, M.; Bienes, R.; Eldridge, D.J.; Marques, M.J. Vegetation cover reduces erosion and enhances soil organic carbon in a vineyard in the central Spain. Catena 2013, 104, 153-160. [CrossRef]

13. EC-JRC (European Commission, Joint Research Centre). Good Agricultural and Environmental Conditions (GAEC); EC, JRC: Brussels, Belgium; Available online: https://marswiki.jrc.ec.europa.eu/wikicap/index.php/ Good_Agricultural_and_Environmental_Conditions_\%28GAEC\%29 (accessed on 11 July 2019).

14. Gómez, J.A.; Guzmán, M.G.; Giráldez, J.V.; Fereres, E. The influence of cover crops and tillage on water and sediment yield, and on nutrient, and organic matter losses in an olive orchard on a sandy loam soil. Soil Tillage Res. 2009, 106, 137-144. [CrossRef]

15. Gómez, J.A.; Sobrinho, T.A.; Giráldez, J.V.; Fereres, E. Soil management effects on runoff, erosion and soil properties in an olive grove of Southern Spain. Soil Tillage Res. 2009, 102, 5-13. [CrossRef]

16. Carpio, A.J.; Castro, J.; Mingo, V.; Tortosa, F.S. Herbaceous cover enhances the squamate reptile community in woody crops. J. Nat. Conserv. 2017, 37, 31-38. [CrossRef]

17. Carpio, A.J.; Castro, J.; Tortosa, F.S. Arthropod biodiversity in olive groves under two soil management systems: Presence versus absence of herbaceous cover crop. Agric. For. Entomol. 2019, 21, 58-68. [CrossRef]

18. Gómez, J.A.; Campos, M.; Guzmán, G.; Castillo-Llanque, F.; Vanwalleghem, T.; Lora, Á.; Giráldez, J.V. Soil erosion control, plant diversity, and arthropod communities under heterogeneous cover crops in an olive orchard. Environ. Sci. Pollut. Res. 2018, 25, 977-989.

19. Guerrero-Casado, J.; Carpio, A.J.; Prada, L.M.; Tortosa, F.S. Short communication. The role of rabbit density and the diversity of weeds in the development of cover crops in olive groves. Span. J. Agric. Res. 2015, $13,7$. [CrossRef]

20. Carpio, A.J.; Soriano, M.A.; Guerrero-Casado, J.; Prada, L.M.; Tortosa, F.S.; Lora, A.; Gómez, J.A. Evaluation of an unpalatable species (Anthemis arvensis L.) as an alternative cover crop in olive groves under high grazing pressure by rabbits. Agric. Ecosyst. Environ. 2017, 246, 48-54. [CrossRef]

21. Conservation Technology Information Center (CTIC). National Survey of Conservation Tillage Practices; CTIC: West Lafayette, IN, USA, 2004.

22. Sarrantonio, M. Building soil fertility and tilth with cover crops. In Managing Cover Crops Profitably, 3rd ed.; Clark, A., Ed.; Sustainable Agriculture Research \& Education (USDA): Beltsville, MD, USA, 2007; pp. 16-24.

23. Evers, G.; Nelson, L.R. Grazing termination date influence on annual rye-grass seed production and reseeding in the South-Eastern USA. Crop. Sci. 2000, 40, 1724-1728. [CrossRef]

24. Neto, A.B.; Savian, J.V.; Schons, R.M.T.; Bonnet, O.J.F.; do Canto, M.W.; de Moraes, A.; Lemaire, G.; de Faccio Carvalho, P.C. Italian ryegrass establishment by self-seeding in integrated crop-livestock systems: Effects of grazing management and crop rotation strategies. Eur. J. Agron. 2014, 53, 67-73. [CrossRef]

25. Soriano, M.A.; Cabezas, J.M.; Ramos, A.; Lora, A.; Gómez, J.A. Characterization of Cover Crops for Use in Olive Groves and Vineyards in Certified Systems under Mediterranean Conditions; Agro Environ 2016, 10th International Symposium on Agriculture and the Environment; Purdue University: West Lafayette, IN, USA, 2016. 
26. Gómez, J.A.; Soriano, M.A. Evaluation of the suitability of three autochthonous herbaceous species as cover crops under Mediterranean conditions through the calibration and validation of a temperature-based phenology model. Agric. Ecosyst. Environ. 2020, 291, 106788. [CrossRef]

27. Kay, Q.O.N. Biological Flora of the British Isles: Anthemis arvensis L. J. Ecol. 1971, 59, 637-648. [CrossRef]

28. Instituto de Investigación y Formación Agraria y Pesquera (IFAPA). Estaciones agroclimáticas; Junta de Andalucía, IFAPA: Seville, Spain; Available online: https://www.juntadeandalucia.es/agriculturaypesca/ ifapa/ria/ (accessed on 11 July 2019).

29. Barrio, I.C.; Villafuerte, R.; Tortosa, F.S. Can cover crops reduce rabbit-induced damages in vineyards in southern Spain? Wildl. Biol. 2012, 18, 88-96. [CrossRef]

30. Riccobono, L.; Maggio, A.; Bruno, M.; Spadaro, V.; Raimondo, F.M. Chemical composition and antimicrobial activity of the essential oils of some species of Anthemis sect. Anthemis (Asteraceae) from Sicily. Nat. Prod. Res. 2017, 31, 2759-2767. [CrossRef] [PubMed]

31. International Union of Soil Sciences (IUSS) Working Group WRB. World Reference Base for Soil Resources 2014, update 2015. International Soil Classification System for Naming Soils and Creating Legends for Soil Maps; World Soil Resources Reports No. 106; FAO: Rome, Italy, 2015.

32. Luscier, J.D.; Thompson, W.L.; Wilson, J.M.; Gorham, B.E.; Dragut, L.D. Using digital photographs and object-based image analysis to estimate percent ground cover in vegetation plots. Front. Ecol. Environ. 2006, 4, 408-413. [CrossRef]

33. Allen, R.G.; Pereira, L.S.; Raes, D.; Martin, S. Crop. Evapotranspiration-Guidelines for Computing Crop Water Requirements; FAO Irrigation and Drainage Paper 56; FAO: Rome, Italy, 1998.

34. Francis, C.; Thornes, J. Runoff hydrographs from three Mediterranean vegetation cover types. In Vegetation and Erosion; Thornes, J.B., Ed.; Wiley: Chichester, UK, 1990; pp. 363-384.

35. Dabney, S.M.; Delgado, J.A.; Reeves, D.W. Using winter cover crops to improve soil and water quality. Commun. Soil Sci. Plant Anal. 2001, 32, 1221-1250. [CrossRef]

36. Gimeno-García, E.; Andreu, V.; Rubio, J. Influence of vegetation recovery on water erosion at short and medium-term after experimental fires in a Mediterranean shrub land. Catena 2007, 69, 150-160. [CrossRef]

37. Salisbury, E.J. Weeds and Aliens; Collins: London, UK, 1961.

38. Schultz, B.; Davison, J. Scentless Chamomile: Taxonomy, Ecology, and Control; University of Nevada, Circular Fact Sheet FS-02-85; Cooperative Extension Service (UNCE): Reno, NV, USA, 2002.

39. Fracchiolla, M.; Terzi, M.; Frabboni, L.; Caramia, D.; Lasorella, C.; de Giorgio, D.; Montemurro, P.; Cazzato, E. Influence of different soil management practices on ground-flora vegetation in an almond orchard. Renew. Agric. Food Syst. 2016, 31, 300-308. [CrossRef] 